\title{
The Influence in Principal Leadership Styles and Its Role in the Academic Achievement of Secondary School Students in Malaysia
}

\author{
Abdullah Ibrahim¹, Aizudin Md Rami², Ruhaizan Sulaiman @ Abdul Rahim¹, Farah Nazrah Mohd \\ Ghazali $^{1}$
}

${ }^{1}$ Center for Fundamental Studies, Universiti Sultan Zainal Abidin, 21300, Terengganu, Malaysia

${ }^{2}$ Faculty of Educational Studies, Universiti Putra Malaysia, 43400, Selangor, Malaysia

\begin{abstract}
Developing academic goals amongst students is a key aspect for achieving excellence across schools in Malaysia. It is meant to act as a benchmark to determine the effectiveness of a principal's leadership. The leadership of a principal, and the school's climate are the main issues which drive the achievement of students across national secondary schools (SMK) in Malaysia. This quantitative study aims to examine the influence and role of a principal's leadership on the school climate, as well as its impact on the student's academic achievement in domestic national secondary schools nationals on the East Coast of Malaysia. A total of 348 teachers were selected across vocational schools in the states of Kelantan, Terengganu and Pahang, through the use of simple random sampling, for the purpose of quantitative reviews. The researchers used the Multifactor Leadership Questionnaire (MLQ) to measure the leadership aspects of the principals, and the Organizational Health Inventory (OHI-M) to measure the climate of the school, as well as the achievement of academic students, which was measured using the CGPA of the schools in the examination areas over the last three years. The analysis of descriptive traits, for example, the number, percentage, scoring average, and the standard deviation was used to describe the demographics of the respondents, and analyse the data using regression, Pearson t-test correlations, and ANOVA. This helped to understand several key leadership factors, i.e., the International Transform Leadership, Tran Witness Leadership, Laissez-Faire Leadership, School Climate, and the Academic Achievement of the hypothesis testing, which was built according to the obtained statistics. The findings showed that the principal's leadership influenced the climate across the school, and the achievement of the students. Therefore, it was proposed that the principal's leadership needs to adopt the Transformational leadership, Transactional leadership, and Laissez-faire leadership as a guide in managing the school's climate, especially in ensuring the teacher's commitments, and the Student Academic Achievements, which can be further enhanced in line with the Malaysian Education Quality Standards 2010 (SKPM), and the Malaysian Education Development Plan 2013 -2025.
\end{abstract}

Key words: Leadership, Malaysia, school principals, school climate

Article Received: 18 October 2020, Revised: 3 November 2020, Accepted: 24 December 2020

\section{INTRODUCTION}

Education in Malaysia is a continuous effort to develop the nation's talents holistically, and integrate it to produce people who are righteous, balanced, and harmonious, in terms of physical, emotional, spiritual and intellectual aspects, based upon the principles of faith and obedience to God (Amir \& Zaidatul 2011). Educational leadership should lead the respective schools, so that their respective management teams are able to develop a concept which is in line with the National Education Philosophy. Leadership can help enable this concept as the core of the education program across all subjects and co-curriculum activities, which will eventually be able to relate to all other implemented programs. It's success will be measured through its outcome of being an essential pillar for an effective education outcome, and the delivery of a balanced and robust education system
(Ahmad, 2006). Leadership is crucial in the effort to formulate an agenda that leads to the appreciation of the National Education Philosophy, in order to produce a generation of Malaysians who have high morals (Fullan, 2011). Charismatic leaders enable students to develop traits which are of noble values, and can be combined through activities in the classroom and outside the classroom (Abdul, 2003). Leadership readiness is very much needed in line with the various continuous noble efforts from the Ministry of Education, which requires the subsequent generation to develop the necessary leadership to face the current and future challenges, and to generate a national identity which covers all aspects in the future (Yahya Don, 2010). These ambitions can only be achieved through high confidence, and responsibility for the quality and 
effectiveness of the education systems used by the leaders.

\section{ISSUE}

Principal leadership plays a role in creating a good school atmosphere and climate. A principal is someone who can plan to improve the excellence of students in a school through the use of discipline, integrity, and act as a good role model. A principal also needs to display good leadership management, extensive community interaction, high intellectual power, and various skills which are needed to improve the school's achievements and excellence. Thus, to achieve Malaysia's desire to become a developed country by 2030, transformation across the education arena must be implemented in an organized and responsible manner, especially to produce balanced human beings who are adept physically, emotionally, spiritually, and intellectually, to meet the challenges at the local and international levels (Amir \& Zaidtul, 2011). No one can deny that the field of education is the foundation for nation-building. Therefore, in order to achieve the necessary excellence in education, the leadership function of the principals is often targeted. In order to create such high-performing schools, there are several characteristics which must be possessed by the principals, of which they must have a far-fetched vision of the world of education, and be able to drive the necessary transformation in an organization (Balyer, 2012).

Apart from that, in the era of globalization, a leader's role is crucial toward ensuring that the tasks and the role of the teachers help to increase the motivation and commitment, for ensuring academic achievement. Thus, the aspect of school climate is a major variable, because it directly affects the student's academic performance, and the contribution of the teachers toward the school's organization (Barnett et al., 2014). An employee who does not feel at peace at his or her job, will not carry out their duties faithfully.

\section{OBJECTIVE}

Identify the influence of a principal's leadership on the school climate, and on the academic achievement of SMK students in the east coast of Malaysia.

\section{METHOD}

The study was designed using a cross-sectional quantitative survey (Cross -sectional survey).
According to Walliman (2019) a survey-based study in research is helpful to explain current events, by generating data in a particular context using a questionnaire. Punch (2014) stated that descriptive survey methods are appropriate for being used to describe the relationship conditions between two variables. The study's design referred to the plan and structure of the investigation used to obtain the necessary evidence, and the answer to the research questions. The approach used to collect information in the study description was achieved by using questionnaires and interview protocols (Walliman, 2019). This study utilised correlation analysis and linear regression, to identify the existence of the relationship between the principal's leadership, and the school's climate. The study collected and analysed numerical data, and further determined the excellence of the leadership style. In addition, demographic factors associated with the principal, such as their age, gender and work experience (years), was also tabulated. Socio-economic factors, the location, and the size of the school were set as the control variables in this study. The MLQ and OHI-M questionnaires were collected from schools on the East Coast, by obtaining the school's information, such as the school's location, size, socio-economic status, academic achievement, and the nature of the leadership.

\section{DISCUSSION}

The Influence of a Principal's Leadership on the School's Climate

The principal's leadership impacted the school's climate. This was evident from the findings of the studies, which showed that the contribution of these aspects to the school's climate was clear to see. The results of the analysis obtained from this study found that the principals' leadership dimensions contributed to the improvement of the climate level across the SMK schools in Kelantan. In addition, the findings of this study also revealed the dimensions of the school's leadership, which was significant in terms of the school's climate, namely it's dimensional counterparts, academic strength, instructional integrity, the influence of resources, and it's collegiality.

The findings of this study showed that principal's leadership practices had a significant influence on the dimension of the academic consolidation, i.e., the Transformational leadership practices, for the 
charismatic dimension of the nature and the dimension of the intellectual stimulation. It was also similar to that of the Transactional leadership practices, for the contingency reward dimension, the active exclusion dimension, and the passive exclusion dimension. For the peer dimension, the study found that the school's leadership practices had a significant influence on this dimension, which were the Transformational leadership practices which aimed for the charismatic dimension of nature, the individual's judgment dimension, the Transactional leadership practices for the contingency rewards dimension, the active exclusion dimension, the dimension passive exclusion, and the Laissez-faire leadership practices. According to Aziz et al., (2020) and Balyer (2012), leaders who practice Transformational leadership and Transactional leadership will create satisfaction amongst the teachers, and the school's climate will improve the student's achievements. It has been proven through this study, that the Transformational leadership, Transactional leadership, and the Laises-faire leadership used by the principals, influence the school's climate, and alleviates the performance of the school's students.

This study also found that leadership practices in the transformational dimension of intellectual stimulation, and the leadership practices in the Transactional dimension of reward contingency, as well as the dimensions of active exclusion, have a significant influence on the dimensions of collegiality, while the dimensions of the strengthening at the academic front, affects the dimensions of the disclosure. This is related to the practice of leadership transformation for the charismatic dimension behaviour, intellectual stimulation, and leadership practices across the Transactional dimensions of the contingent reward, the dimensions of active exclusion, and the passive exclusion dimension. This finding is in line with the findings of Barret et al., (2014); Birasnav (2014), who found that the Transformational leadership amongst school leaders have a moderately positive effect on the school's climate in terms of the teacher's responsibility in accepting reforms. It was found that the intellectual stimulus dimension had a strong positive effect on the responsibilities of the teachers, and the extra efforts of the teachers, while the dimension of individual judgment displayed a very weak influence.

Moreover, it was found that leadership practices which influenced the intonation dimension were the Transformational leadership practices for the charismatic dimension of behaviour, and the Transactional leadership practices for passive exclusion dimensions. In addition, the study also found that leadership practices for the Transformational charismatic dimensional behaviour, and the intellectual stimulation of the leadership practices for the Transactional contingent reward dimension, as well as the dimension of active exclusion and passive dimensions of exclusion, had a significant effect on the dimensions of collegiality. The importance of the Transformational leadership practices and the Transactional leadership practices on the school's climate was supported by studies conducted by Day et al. (2009); Mamat et al., (2019) and Aragon et al. (2007).

Similar findings were also observed by studies from Andreescu and Vito (2010), who found that Transformational leaders tend to influence an employee's creativity. Al-Anzi (2009) also found that top management support significantly affects a company's performance. The findings of Bai et al. (2014) stated that leaders who practice Transformational leadership influence an employee's management in terms of the development of the information systems, as well as the support of the employees in developing these systems and achieving the necessary flexibility. Thus, Transformational leaders focus on different organizational development strategies for implementation (Chinthala, 2014). In addition, the charismatic influence of a leader's behaviour also encourages employees to engage in beneficial activities for the organization's profit. As a result, these leaders will improve the creativity and innovative spirit of the workers in producing an encouraging output.

If a school wants to achieve success, school leaders need to set different goals at different times, so that teachers always work hard to achieve these goals (Balyer 2012). This is because various school members have different expectations for the school's development. School leaders need to increase the Transformational leadership aspect in their leadership practices to create good conditions 
to stimulate the spirit of the teachers to a higher degree, by placing different groups of teachers in different situations, according to the suitability of the teachers, so that they are more motivated to work, be respected, trusted, and are able to increase their job satisfaction result, which will indirectly help them achieve the goals which have been set. Hence, school leaders need to continue setting new goals, and choose different leadership practices for different people, by playing an important role in encouraging continuous school improvement, and promoting school development.

Overall, a principal's leadership practices need to embrace Transformational leadership practices (charismatic (nature), charismatic (behaviour), motivational aspects, intellectual stimulation and individual judgment), Transactional leadership practices (contingency rewards, active exclusion and passive exclusion), and Laissez - faire leadership practices. They were found to influence the dimensions of the school's climate (academic strengthening, institutional integrity, camaraderie, peer respect, and the influence of resources). This means that the principal's leadership directly impacts the climate across the SMK schools in the East Coast. Therefore, it is appropriate for the Kelantan Education Department (JPN Kelantan) to always emphasizes on the leadership of the school leaders across SMKs, as the principal's leadership has a big impact on the school's climate, which will also affect the student's academic achievement.

\section{CONCLUSION}

This study has been successfully implemented, and the results of the study will provide useful contributions toward the leadership of principals, middle leaders in schools, teachers, and the Ministry of Education Malaysia, which will benefit the principals across the SMKs, in an effort to meet the criteria outlined in the Malaysian Education Quality Standards (SKPM 2010). The study aims to examine the role of the principal's leadership, and the school's climate on student's achievement across SMKs in the East Coast states. It has achieved the primary research objectives, and has successfully proven that there is an influence between the principal's leadership, the school's climate, and the student's achievement. This study involved 350 teachers across vocational schools in the states of Kelantan, Terengganu and Pahang, across 90 schools in 10 PPD districts. In this SMK, it can be seen that the practice of Transformational leadership and Transactional leadership by the principal is maintained at a high level, while the laisez faire leadership as a whole, was at a moderate level. The school's climate, and the level of the student's achievements were also found to be at a high level.

The results of the study found that the school's climate and the student's achievements did not differ in terms of gender, age, and teaching experience. However, after further analysis of the dimensions of the school's climate, and every aspect of the student's achievement, several dimensions across these two variables were found to exist based on demographic factors, such as gender, age, and teaching experience. In general, there was a relationship between the school's leadership and climate, as well as the school's leadership with that of the student's achievements and the school's climate with that of the student's achievements. This study has proven that the principal's leadership influences the school's climate, and affects the student's achievements in vocational schools in Kelantan.

It can be concluded that the findings of the study were in line with that across historical academic works. Firstly, the school's climate played a role which was very important in influencing the leadership of the principals. Its importance can be seen in the relationship and influence of the school's climate of with that of the leadership principles, and the achievements of the students. Secondly, the principal's leadership also played an important role in influencing the student's achievement.

Thirdly, there were no differences in terms of gender, age, and teaching experiences on the school's climate and the student's achievement levels. Fourthly, the results of the analysis can help define the dimensions of the school's climate, and the leadership of the principals, which is a major predictor and significant aspect for the strengthening and improvisation of the student's achievements. Lastly, it has been noted that the formulation of the findings act as a major outcome for the study of the principal's influence on the schools, especially for the principals leadership style, as well as the behaviour of the teachers in vocational schools in the state of Kelantan, toward increasing the level of academic integrity. 


\section{References}

Andreescu, V., \& Vito, G. F. (2010). An exploratory study on Ideal Leadership Behavior: the opinions of American Police managers. International Journal of Police Science \& Management, 12 (4), 567-583.

Abdul Ghani Kanesan Abdullah (2003). An investigation of leadership substitutes as moderator of principles' transformational leadership behaviour. Tesis Doktor Falsafah. Universiti Sains Malaysia, Pulau Pinang

Ahmad Zabidi Abdul Razak. (2006). Ciri iklim sekolah berkesan: Implikasinya terhadap motivasi pembelajaran. Jurnal Pendidikan. 31, 3-19.

Al-Anzi, N.M. (2009).Workplace environment and its impact on employee performance. MBA thesis, submitted to Open University of Malaysia.

Amir \& Zaidatol (2011). Transformational leadership and its predictive effects on leadership effectiveness. International Journal of Business and Social Science, 3, 186-197.

Aragon-Correa, J.A., Garcia-Morales, V.J. \& CordonPozo, E. (2007). Leadership and organizational learning's role on innovation and performance: lessons from Spain. Industrial Marketing Management, 36, 349-359.

Ash, R. C. \& Persall, J.M. (2000).hThe Principal as Chief Learning Officer: Developing Teacher Leaders. NASSP Bulletin, vol. 84 (15). Dimuat turun pada 27.3.2013 dari bul.sagepub.com, Universiti Putra Malaysia. DOI: 10.1177/019263650008461604

Aziz, F., Md Rami, A., Razali, F., \& Mahadi, N. (2020). The influence of leadership style towards technology acceptance in organization. International Journal of Advanced Science and Technology, 29(7s), 218-225.

Balyer, A. (2012). Transformational leadership behaviors of school principals: A qualitative research based on teachers' perceptions. International online journal of educational sciences, 4(3), 581-591.

Barling, J., Kelloway, E.K. \& Iverson, R.D. (2003). High quality work, job satisfaction and occupational injuries. Journal of Applied Psychology, 88(2), 276-283.

Barnett, K., McCormick, J. and Conners, R. (2001). Transformational leadership: panacea, placebo, or problem?. Journal of Educational Administration, 39(1), 24-46.

Barrett, Catherine, Breyer \& Robert (2014). The influence of effective leadership on teaching and learning. Journal of Research Initiatives, 1(2), 3.

Bartlett, J.E., Kotrlik, J.W \& Higgins, C.C. (2001).

Organizational
Birasnav, M. (2014). Relationship between transformational leadership behaviors and manufacturing strategy. International Journal of Organizational Analysis, 22(2), 205 - 223

Bai, N., Piri, R., \& Piri, A. (2014). Investigating school organizational climate and job satisfaction from Kalale physical education teachers' point of view. Research Journal of Sport Science, 2(2), 45-49.

Bhargavi, S. \& Yaseen, A., 2016. Leadership Styles and Organizational Performance. Strategic Management Quarterly, 4(1), pp. 87-117.

Chinthala, G. (2014). Organizational climate a predictor of job satisfaction among teachers. International Journal of Research (IJR), 1(6), 880-886.

Day, C., Sammons, P., Hopkins, D., Harris, A., Leithwood, K., Qing Gu, Brown, E., Ataridou, E., Kington, A. (2009). The Impact of School Leadershipp On Pupil Outcomes. National College for School Leadership. Nottingham: University of Nottingham.

Mamat, N., Rami, A., Abdullah, R., Amat Simin, M. H., \& Hashim, S. S. (2019). Malay language teaching and learning strategies among orang asli students in Terengganu. International Journal of Recent Technology and Engineering, 8(1C2), 1158-1161.

Punch, K.F. (2014). Introduction to Social Research: Quantitative \& Qualitative Approaches. Thousand Oaks: Sage Publications.

Rami, A. M., Aziz, F., Razali, F., \& Ibrahim, A. (2020a). Effective local leadership to a successful council in the state of Terengganu, Malaysia. International Journal of Advanced Science and Technology, 29(7 Special Issue), 205-210.

Rami, A. M., Aziz, F., Razali, F., \& Yusof, M. R. (2020b). Leadership and ICTs implementation for rural development. International Journal of Advanced Science and Technology, 29(7 Special Issue), 531-535.

Rami, A. M., Simin, H., Abdullah, R., \& Ibrahim, A. (2019). Community leader in enhancing rural economic growth in state of Terengganu, Malaysia. International Journal of Recent Technology and Engineering, 8(2 Special Issue 11), 680-684.

Sergiovanni, T. J. (1996). Leadership for the schoolhouse: how is it different? Why is it important?. Sacramento: Jossey-Bass.

Walliman, N. (2019). Your Research Project: Designing, Planning and Getting Started $\left(4^{\text {th }}\right.$ Edition). Oxford Brookes: SAGE

Yukl, G. (2013). Leadership in Organizations (7th ed.). New Jersey: Prentice Hall. 
